\title{
A Task-Based Approach to Creating English Presentations in Extracurricular Settings
}

\section{Sachi Oshima}

Tsuda University

\section{Reference Data}

Oshima, S. (2021). A task-based approach to creating English presentations in extracurricular settings. In P. Clements, R. Derrah, \& P. Ferguson (Eds.), Communities of teachers \& learners. JALT. https://doi.org/10.37546/JALTPCP2020-33

Twelve university students made an English presentation to introduce various puppet theaters from around the world at an international conference as an extracurricular project. Considering the English presentation as a task for the developing background knowledge of the topic conducting research on puppet theaters in each country, writing and developing backgound know and of the topic, conducting rearch on puppet theaters in each country, writing and revising a presentation script, and practicing making a presentation. The result of this project showed that TBLT worked effectively in encouraging students to be actively involved in these four steps, utilize all four skills for a real-world purpose, and successfully realize the English presentation. The students reported a high degree of satisfaction and a desire to participate in more opportunities to communicate with foreign people. These steps can be applied to regular English lessons to help students to make English presentations.

大学生12名が課外活動の一環で、国際会議において世界の人形劇文化についての英語プレゼンテーションを行った。教 師は、英語プレゼンテーションをタスクと考え、Task-Based Language Teaching (TBLT)を導入し、(1) 学生の背景知識の䤑成、 (2) 各国の人形劇文化についての調査実施、(3) プレゼンテーション原稿の作文・校正、(4) 発表練習、という四つのステップ を設定した。結果、TBLTは学生が各ステップに積極的に取り組み、4技能(LSRW)を総合的に活用し、英語プレゼンテーション を実現するのに効果的であることが分かった。学生のプレゼンテーションは成功し、学生からは高い満足度が示されたまた 外国人とコシューケーションが取れる機会にもっと参加したいとの意向が示された。ののステップは、通常授業においてプレ ゼンテーションを指導する際にも適用できると考えられる。

$n$ response to government encouragement starting in the 2000 s, the number of Lapanese public and private universities making partnership agreements with local prefectural and municipal governments began gradually increasing (Asaoka \& Sawada, 2017; Fukanuma, 2010; Nakatsuka \& Odagiri, 2016). According to Nakatsuka and
Odagiri (2016), these agreements arose from two particular policies. First, due to the 2006 revision of the Basic Act on Education, universities became officially required to contribute to the development of regional communities by broadly disseminating the results of their educational activities. Secondly, following the implementation of the National Spatial Strategy in 2008, prefectural and municipal governments were encouraged to collaborate with universities for their regional development. Today, universities are expected to contribute to addressing regional issues while conducting educational activities outside their campuses. According to a survey by Asaoka and Sawada (2017), from 2006 to 2012, the number of these agreements steadily increased every year, and since 2013, more than 200 such agreements have been made annually. As of March 2016, the number of these agreements has reached 1,510. Following this trend, Tsuda University, where the author works as an English teacher, has also made a partnership agreement with several cities and organizations in Japan so that the students can be involved in field studies and practically learn about and experience regional revitalization, which is an important issue in Japan today (Fukanuma, 2010; Nakatsuka and Odagiri, 2016).

Tsuda University and lida City in Nagano Prefecture started collaborating in April 2018. That year was meaningful for lida City because the World Puppet Festival and the annual General Assembly of Association Internationale des Villes Amies de la Marionnette [International Association of Puppet Friendly Cities] (AVIAMA) were held there for the first time in August. The 2018 AVIAMA assembly was attended by representatives, mainly puppet theater professionals, of 16 cities from eight countries or regions: France, Spain, Belgium, the Czech Republic, Poland, Korea, Taiwan, and Japan.

Based on the agreement, for this special occasion, the university's students were expected to make an English presentation introducing puppet theaters in each representative's country at the opening reception. In other words, they were given a concrete task to be accomplished. Therefore, the author employed task-based language teaching (TBLT) while instructing them as an extracurricular activity. 
The purpose of this paper is to show the effectiveness of TBLT in the development of the students' English presentation. More specifically, it addresses whether and how the four steps set by the author based on TBLT effectively helped the students to create an English presentation.

\section{Theoretical Background}

According to Ellis and Shintani (2014), TBLT "aims to develop learners' communicative competence by engaging them in meaning-focused communication through the performance of tasks" (p. 135). In this project, the author considered the English presentation at the AVIAMA General Assembly to be a task and employed TBLT to instruct the students. Therefore, this literature review first focuses on the definitions of a task and shows whether the presentation at the AVIAMA General Assembly qualified as a task. Then, three principal phases in implementing TBLT are reviewed, and lastly, previous studies suggesting the effects of TBLT are introduced.

\section{Definition of Tasks}

"What is a task?" seems to be a simple question, but there have been a variety of definitions and classifications (Ellis \& Shintani, 2014; Jackson \& Burth, 2017; Richards \& Rodgers, 2014; Van den Branden, 2006). Among the various definitions, Ellis (2003) and Ellis and Shintani (2014) suggested four criteria for defining a "task."

The first criterion is a primary focus on meaning. Ellis and Shintani (2014) explained that here, "meaning" refers to semantic and pragmatic meanings. Learners focus on encoding and decoding messages rather than linguistic forms. From the teacher's point of view, a task is provided to students not to make them practice language features but to "create communicative contexts for using language" (Ellis \& Shintani, 2014, p. 136). The second criterion is the existence of information gaps between learners and their interlocutors; for example, there should be a need to convey information to others. Thirdly, learners should largely rely on their own linguistic and nonlinguistic resources to complete the activity, which means that "learners are not 'taught' the language they will need to perform a task" (Ellis \& Shintani, 2014, p. 135). Lastly, a clearly defined outcome other than the use of language is set; in other words, learners are given a goal they are expected to complete, and language serves as the means for achieving the outcome.

The above criteria support the author's decision that the English presentation at the AVIAMA assembly was a task for the students:
1. While creating an English presentation, the students primarily focused not on language but on the content of the presentation; therefore, their primary focus was on meaning.

2. The students were expected to make a presentation and convey their messages to the audience; therefore, there was an information gap between the students and the audience.

3. To create the English presentation, the students had to learn the necessary knowledge and language by themselves. In other words, they largely relied on their own resources.

4. The defined outcome was the presentation at the conference, and English was the means for achieving the outcome.

\section{Three Phases in Implementing TBLT}

Following Richards and Rodgers's (2014) explanation that various tasks are employed in various lesson formats, there are different terms used to describe task-based lesson designs. Several researchers have proposed three phases in task-based lessons: pre-task, main-task, and post-task (Ellis \& Shintani, 2014; Richards \& Rodgers, 2014; Willis, 1996).

The pre-task phase is used for introducing a topic and task. In many cases, teachers provide students with the necessary vocabulary to perform the task, show models (such as a model essay or performance), and provide students time to brainstorm or plan how to do the task. "Schema-developing" (Ellis \& Shintani, 2014, p. 142), in other words, developing background knowledge, is also conducted in the pre-task phase, and the teachers provide, elicit, and extend students' knowledge of the topic. Background knowledge can also be defined as prior or basic knowledge utilized for interpreting a text. Without background knowledge, readers and listeners often find it difficult or even impossible to understand what they read and listen to (Grabe \& Stoller, 2011; Li \& D'Angelo, 2016; Richards \& Burns, 2012). Therefore, to facilitate the students' comprehension, developing the background knowledge, in other words, schemadeveloping is necessary.

In the main-task phase, students, often in pairs or groups, use their existing linguistic and nonlinguistic resources and try to accomplish the task. Teachers monitor the students, encourage them to communicate effectively to perform the task, and take time to provide explicit instruction on some linguistic features. Finally, in the post-task phase, students report and share the outcome of the task. Teachers also give comments and provide feedback on their performance. 
Considering that the students in this project were taking regular English lessons on campus but did not know much about puppet theaters, these pre-task, main-task, and post-task phases seemed as though they would be effective to help them realize the English presentation at the AVIAMA General Assembly.

\section{Effects of TBLT}

Previous studies have uncovered the positive effects of TBLT on learners' L2 performance. Bryfonski and McKay (2017) conducted a meta-analysis examining the effects of TBLT implementation in language classrooms. They selected 52 studies based on criteria such as "studies accessible in English" (p. 609) and "studies that examined the effects of the TBLT program's implementation on some outcome measure" (p. 610). In particular, they focused on 29 between-group studies which showed an overall positive and strong effect size for the effectiveness of TBLT programs on L2 learning outcomes, compared with either a comparison or control group. The researchers also examined 13 perception studies and reported that almost $80 \%$ of the participants' perceptions of TBLT was positive.

Other researchers have indicated that TBLT is also effective for raising learners' motivation. Van den Branden (2016) showed that one benefit of practicing TBLT is that tasks can enhance learners' motivation in class. Chen and Brown (2012), employing TBLT in writing instruction for high-beginner-level adult learners, suggested that the learners were engaged in a "dynamic motivational process" (p. 450); they were motivated by the tasks, and their task completion in turn led to motivation for completing subsequent tasks.

These studies have suggested that TBLT can positively affect learners' L2 outcomes, bring a high degree of satisfaction, and enhance their motivation. That is why the autho decided to employ TBLT while helping the students to create an English presentation.

\section{Method}

\section{Participants}

Participants were solicited by the university in April 2018. Tsuda University has two campuses, both in Tokyo, and is located about four hours by bus from lida City. The requirements for the participants were to: (a) visit and stay for about three days in lida City in August 2018, (b) interact with the representatives from overseas, and (c) make a group presentation in English introducing the puppet theaters of 16 cities at the opening reception of the conference.
Twelve students voluntarily participated in this project. The author estimated their English proficiency to be from intermediate to upper-intermediate (approximately Common European Framework of Reference B1 to B2). Of the 12, nine second-year students majored in policy studies and studied at one campus, while three students (one second-year and two first-year students) majored in liberal arts and were located in the other campus. Therefore, the students and teachers, including the author of this paper, communicated by holding online meetings and using emails and the instant message application LINE. To better understand their perceptions, a questionnaire was administered to the students using the online survey platform SurveyMonkey (www.surveymonkey.com) after the completion of the English presentation at the AVIAMA General Assembly. The questionnaire was voluntary, and of the 12 students, nine answered the questionnaire. To get their honest opinions, the questionnaire was anonymous and did not require the students to disclose their names. The questionnaire was conducted in the students' L1, Japanese (see Appendix for the questionnaire items), and the students' answers cited in this paper were translated from Japanese by the author. All participants gave informed consent to the author.

Table 1

Reasons for Participation in this Project

\begin{tabular}{lc}
\hline \multicolumn{1}{c}{ Reason } & Number \\
\hline I was interested in regional revitalization. & 7 \\
I wanted to use English for real-world purposes. & 5 \\
I was interested in performing arts including puppet theaters. & 5 \\
I was interested in intercultural exchange. & 4 \\
Others & 0 \\
\hline
\end{tabular}

Note. $N=9$. Multiple answers allowed.

The students' motives for participating in this project are shown in Table 1. The most common motive was their interest in regional revitalization. The second most common motives were their interests in performing arts, including puppet theaters, and their hope to use English for real-world purposes. 
JALT2020

COMMUNITIES OF
TEACHERS \& LEARNERS

\section{Teachers}

Two teachers were involved in this project. One was a professor at Tsuda University who oversaw the whole project with lida City and acted as a liaison between the university and lida City. The other was the author of this paper, a research fellow and an English teacher at Tsuda University, and was mainly in charge of teaching the students to make the presentation. She had experienced managing several performing arts events before, which led to her involvement in this project.

\section{Procedure}

The instruction for making the presentation was conducted from May to August 2018 by the author as an extracurricular project. In the first two months, the students and teachers held biweekly online meetings and also communicated by email. From July until the AVIAMA assembly in August, the author held individual or small group meetings twice or three times per student depending on their progress. The students went through the four steps illustrated in Figure 1. All four skills were integrated into these steps to accomplish the task. More specifically, while creating the presentation, the students had to use English to read various references to conduct research, write and revise a script, and practice the presentation.

Figure 1

The Four Steps of Creating a Presentation

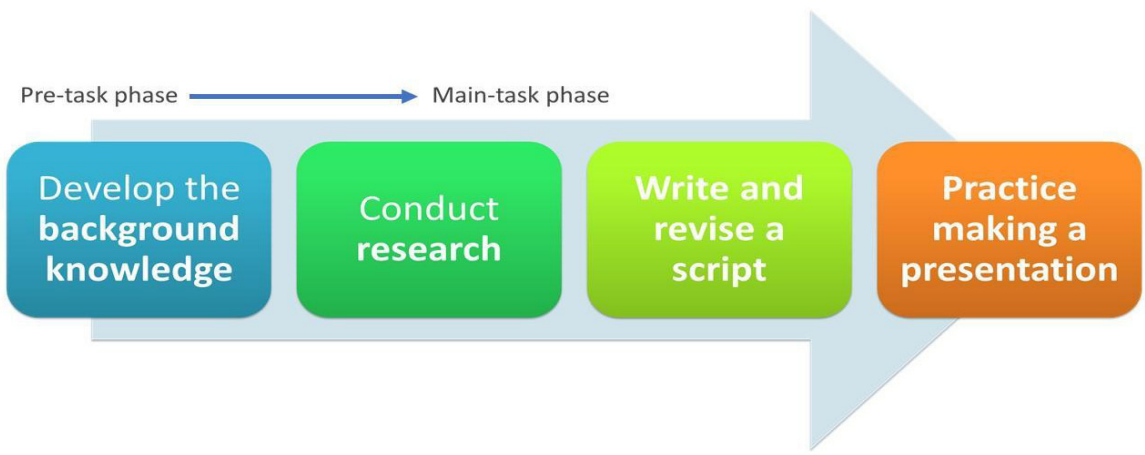

\section{Step 1: Developing the Background Knowledge}

No students participating in this project majored in performing arts. Some of them had an interest in theater or had experienced theatrical plays before; however, from chatting with the students, the teacher found that none of them had any knowledge of puppet theaters at the beginning of this project. Therefore, it was considered necessary to develop their background knowledge first. The teacher arranged two opportunities for the students to do field study. In both, the students used their L1, Japanese. The first was a visit to the Japanese traditional marionette theater company Isshi-za, where the puppeteer explained traditional puppets in Japan and his productions. The students also learned how to hold and operate a puppet (see Figure 2). Secondly, they visited executives of the Foundation Modern Puppet Theater, which is the leading puppet organization in Japan and has introduced both Japanese and overseas puppet theaters to Japanese audiences. The students interviewed the executives and learned about puppet cultures in Japan and in other countries, especially those participating in the 2018 AVIAMA General Assembly.

Figure 2

Visiting the traditional marionette company Isshi-za (all those depicted here gave written consent to the author for their photographs to be included).
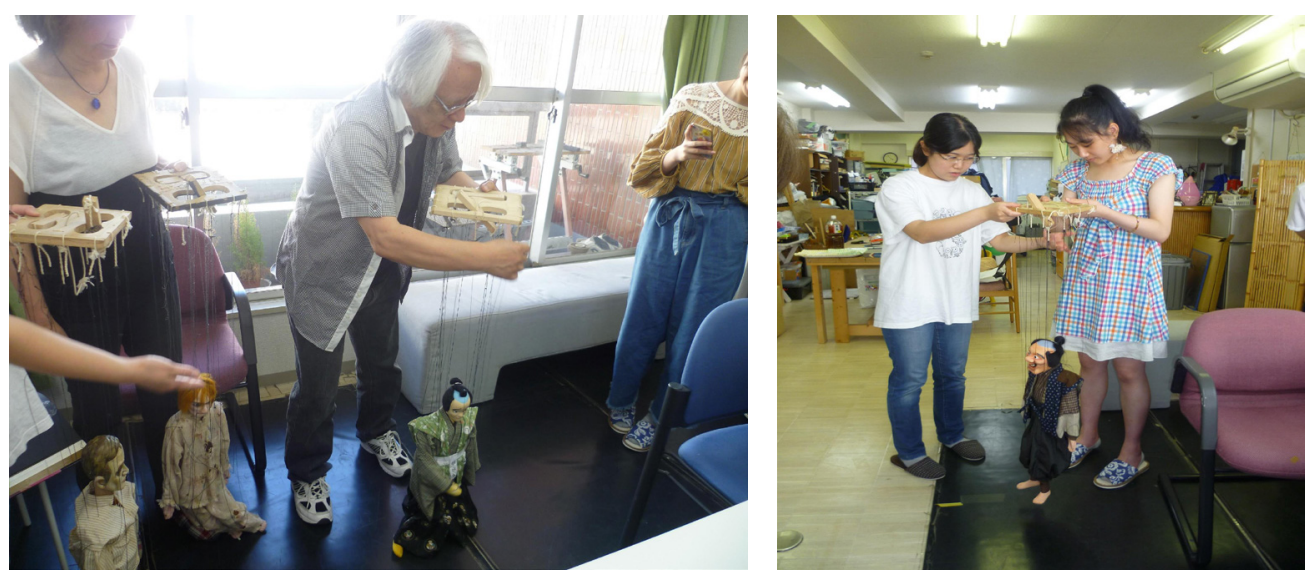
JALT2020

COMMUNITIES OF
TEACHERS \& LEARNERS

\section{Step 2: Conducting Research}

Each of the 12 students became a member of two or three study groups, for a total of 16 groups representing the 16 cities participating in the AVIAMA General Assembly. The students started research on puppet theaters in each city.

Table 2

Sources Used for Research by the Students

\begin{tabular}{lc}
\multicolumn{1}{c}{ Source } & Number \\
\hline English sources on the Internet & 9 \\
Japanese sources on the Internet & 8 \\
Visiting organizations & 4 \\
Japanese sources at the library & 3 \\
English sources at the library & 1 \\
Others (Interviewing on the phone) & 1 \\
\hline
\end{tabular}

Note. $N=9$. Multiple answers allowed.

According to the questionnaire, all respondents $(N=9)$ answered that they read English sources on the Internet (Table 2). To conduct research and gain the necessary information to make a presentation, the students had to purposefully read many English sources. Depending on the students' needs, the teacher provided information, such as cultural organizations from each country which the students could visit, and references including websites and books they could refer to.

\section{Step 3: Writing and Revising a Script}

Based on their research, first, the students in each study group wrote a draft and made PowerPoint slides to introduce each city. Then, the teacher checked each group's draft and slides and gave feedback on content and grammar. For instance, when a draft seemed lacking in information, the teacher told the students to research further and develop the content. When a draft contained numerous grammatical errors, she indicated the location to be revised so that the students could correct these errors themselves. Depending on the quality of drafts, the students and the teacher repeated this sequence several times until each draft was finalized.
While writing a draft on each city, the teacher asked the students to think of the flow of the presentation. More specifically, they thought of how to start the presentation, how to sequence the 16 cities, how to make the transition from one city to another, and how to conclude the presentation. Some of the students, who had already finished writing drafts on their cities, started writing the opening and closing parts of the overall presentation, on which the teacher also commented.

Finally, using the online browser-based word processor Google Docs, the students combined all of the drafts into one long script and all of the slides into one slideshow. Although the students had considered the flow of the presentation in advance, once combining all the drafts into one script, they found many parts which were hard to follow or not coherent. Therefore, all the students and teachers, connected by Google Docs, edited the combined script online together so that the script became logically organized.

\section{Step 4: Practicing}

After editing the combined script, the students practiced their presentation for three days, spending 12 hours in total. From the 12 students, five voluntarily became presenters. These five presenters practiced giving the presentation in English. The other students and the teachers listened to the presentation and gave feedback. If the listeners felt that any words or phrases were unclear or unnatural, the students and teachers further revised the scripts and slides.

Through these four steps, the students and the teachers finalized the presentation scripts and slides. The script and slides can be viewed on Tsuda University's website (Oshima et al., 2019).

\section{Results and Discussion}

The task, or in other words, the English presentation was successfully performed (An excerpt of the students' presentation can be viewed on the official JALT YouTube channel at https://youtu.be/7vgl5tiERMw). When the presenters introduced each country or region, the audience reacted with enthusiastic cheers. After the presentation, audience members gave many favorable comments to the students and teachers. For instance, the representatives from Spain said that they enjoyed the presentation very much, and one from Belgium said that he had participated in the production which had been introduced in the presentation. The teachers were also complimented on aspects such as the 
potential for this presentation to be a precious document comprehensively introducing the world puppet history and cultures.

Table 3

Students' Satisfaction with the English Presentation

\begin{tabular}{lcc}
\hline & Degree & Number \\
\hline Very satisfied & 2 \\
Satisfied & 6 \\
Unsatisfied & 1 \\
Very unsatisfied & 0 \\
\hline
\end{tabular}

Note. $N=9$.

The post-presentation questionnaire showed the students' high degree of satisfaction (Table 3). Among the nine respondents, eight students' reaction (89\%) to the presentation was "very satisfied" or "satisfied." Although one student answered "unsatisfied," her reaction could be interpreted as being due to her high motivation because in her comments, she wrote in Japanese, "I could have deepened the content more, and I could have practiced speaking more."

Table 4

Willingness to Participate in Future Activities

\begin{tabular}{lc}
\hline \multicolumn{1}{c}{ Future activities } & Number \\
\hline Having more opportunities to communicate with foreign people & 8 \\
Participating in the projects of regional revitalization at Tsuda & 8 \\
Participating in intercultural exchange programs & 6 \\
Finding more opportunities to make an English presentation & 5 \\
Others & 3 \\
Studying overseas & 1 \\
\hline
\end{tabular}

Note. $N=9$. Multiple answers allowed.
Moreover, this English presentation enhanced the students' motivation for future activities (Table 4), and they showed a willingness to participate in similar activities. One student wrote the following comment in the questionnaire:

Based on our research, I could talk with puppet theater professionals, discover new things, and learn more about other countries, all of which were very meaningful for me. I want to participate in this kind of intercultural exchange project again.... I could learn a lot of things, such as how to research, how to make a presentation, and how to attend to the guests.

\section{Conclusion}

The results of this project showed the effectiveness of TBLT in the creation of an English presentation at an international conference. TBLT implementation encouraged the students to be actively involved in each of the four steps, utilize all four skillslistening, speaking, reading, and writing-for a real-world purpose, and successfully realize the English presentation. The students' response to the post-presentation questionnaire showed a high degree of satisfaction.

It cannot be denied that this project has several limitations which interfere with generalizability. First, it might be argued that this presentation was only made possible because an authentic international setting was provided. The English presentation at the 2018 AVIAMA General Assembly was a result of the partnership agreement between Tsuda University and lida City, and all instruction was conducted as an extracurricular activity. Additionally, it might also be pointed out that the presentation was successful because the students were more highly motivated than typical Japanese EFL college students, given that they voluntarily participated in this project. However, as previous studies (for example, Mahdi, 2015; Sakai \& Koike, 2008) suggested, extracurricular activities themselves can be a motivator for students to learn English. Sakai and Koike (2008) showed that even short-term participation in international events as volunteers facilitated the improvement of students' motivation to learn English. Therefore, teachers may consider exploring whether their institutions already have similar partnership agreements which can lead to opportunities for students to use English in real-life situations. If there are no such agreements, it is recommended to look for international events in which students can participate as extracurricular activities.

Another limitation was the small sample size with the questionnaire results. The author could not obtain responses from three of the 12 students, which lowered the 
validity of the questionnaire results. Future studies can include follow-up interviews or at least make questionnaires obligatory for students who voluntarily participate in a project.

Other than in extracurricular activities, the proposed four steps based on TBLT can be also effective in regular English lessons to teach students how to make English presentations. In a 15-week course for the four skills, this presentation using four steps can be a course project. For a listening and speaking course, still, the four steps can scaffold students to successfully make a presentation. Although instruction would vary depending on students' English proficiency and classroom settings, one of the following points, which correspond to the four steps, can be applicable for a wider range of students:

1. As the students here had researched world puppet culture, choosing an authentic topic can motivate students to do research and create an English presentation.

2. Regardless of the topic and students' English proficiency, it is necessary to ensure students' background knowledge. During this project, one student said that she could not have understood what a book said without understanding the basis of puppet theaters. Ensuring and, if necessary, developing background knowledge can aid students' reading comprehension.

3. While having students write a script, teachers' feedback over the course of multiple drafts is essential. Although it was time-consuming, the quality of the students' scripts greatly improved through several revisions.

4. Encouraging students to take a listener's point of view is effective in refining the script and making a more appealing presentation. Even when presentation scripts were grammatically correct, listeners sometimes found it difficult to comprehend the presentation if the word choice, sentence length, and delivery speed were not appropriate. Conducting rehearsals provided the students opportunities to notice this.

The above four steps using TBLT can encourage students to utilize all four skills of English as a means of communication and successfully accomplish a task. Although a large number of studies have supported the effectiveness of TBLT, there are not enough studies targeting Japanese EFL college students, as Bryfonski and Mckay's (2017) metaanalysis did not include any study targeting L1 Japanese learners. More studies are needed to examine the effectiveness of TBLT on Japanese EFL students, and this paper partially addresses this need. For future studies, it is worth examining how students with different levels of English proficiency and motivation in regular classroom settings respond to the four steps using TBLT.

\section{Acknowledgements}

The students' extra-curricular activity shown in this paper was supported by the Suntory Foundation, the Center for Collaboration and Partnership at Tsuda University, and lida City. I would like to thank Yukiko Ito for her guidance in implementing this project. I also acknowledge the helpful comments provided by the anonymous reviewers.

\section{Bio Data}

Sachi Oshima is a research fellow at the Research Institute for Policy Studies, Tsuda University. After working at the Japan Foundation as a chief officer, she is currently a teacher at Tsuda University, Shibaura Institute of Technology, Tamagawa University, and Tokyo Future University. Her research interests are related to TESOL and intercultural exchange projects. <s-oshima@tsuda.ac.jp >

\section{References}

Asaoka, Y., \& Sawada, S. (2017). 大学と連携する自治体の地域戦略一自治体一大学連携の現状一 [Regional strategies of local governments collaborating with universities: Current situation of partnership between local governments and universities]. Retrieved from https://www.jichiken. jp/article/0041/

Bryfonski, L., \& McKay, T. H. (2017). TBLT implementation and evaluation: A meta-analysis. Language Teaching Research, 23(5), 603-632. https://doi.org/10.1177/1362168817744389

Chen, J. C., \& Brown, K. L. (2012). The effects of authentic audience on English as a second language (ESL) writers: A task-based, computer-mediated approach. Computer Assisted Language Learning, 25(5), 435-454. https://doi.org/10.1080/09588221.2011.606224

Ellis, R. (2003). Task-based language learning and teaching. Oxford University Press.

Ellis, R., \& Shintani, N. (2014). Exploring language pedagogy through second language acquisition research. Routledge.

Fukanuma, H. (2010). 大学と地域の連携一継続の効果と課題一 [Partnership between universities and communities: Effects of continuing and its challenges]. 日本政策金融公庫論集[Quarterly Research Report of Japan Finance Corporation], 7, 21-47. Retrieved from https://www.jfc.go.jp/n/findings/ pdf/ronbun1005_02.pdf

Grabe, W., \& Stoller, F. L. (2011). Teaching and researching reading (2nd ed.). Routledge.

Jackson, D. O., \& Burth, A. R. (2017). Complementary theoretical perspectives on task-based classroom realities. TESOL Quarterly, 51(3), 493-506. https://doi.org/10.1002/tesq.393 


\section{JALT2020}

COMMUNITIES OF
Li, M., \& D’Angelo, N. (2016). Higher-level processes in second language reading comprehension. In X. Chen, V. Dronjic, \& R. Helms-Park (Eds.), Reading in a second language (pp. 159-194). Routledge.

Mahdi, D. A. (2015). Motivating reluctant EFL students to talk in class: Strategies and tactics. Theory and Practice in Language Studies, 5(8), 1703-1709. http://dx.doi.org/10.17507/tpls.0508.22

Nakatsuka, M., \& Odagiri, T. (2016). 大学地域連携の実態と課題 [Reality and challenges in community-university partnership]. 農村計画学会誌 [Journal of Rural Planning], 35(1), 6-11. https://doi.org/10.2750/arp.35.6

Oshima, S., Yamaguchi, M., Masuda, T., \& Nakagawa, T. (2019). 人形劇の友・友好都市国際協会 総会サポートを通した国際文化交流 [Intercultural exchange through puppet culture]. 津田塾大 学総合政策研究所報 [Institute of Policy Studies Report]. Retrieved from https://cps-labs.tsuda. ac.jp/2019/07/19/

Richards, J. C., \& Burns, A. (2012). Tips for teaching listening: A practical approach. Pearson Education.

Richards, J. C., \& Rodgers, T. S. (2014). Approaches and methods in language teaching (3rd ed.). Cambridge University Press.

Sakai, H., \& Koike, H. (2008). 日本語話者大学生の英語学習動機の変化 [Changes in Japanese university students' motivation to learn English: Effects of volunteering in an international event]. JALT Journal, 39(1), 51-68. https://doi.org/10.37546/JALTJJ30.1-3

Van den Branden, K. (2006). Task-based language education: From theory to practice. Cambridge University Press.

Van den Branden, K. (2016). The role of teachers in task-based language education. Annual Review of Applied Linguistics, 36, 164-181. https://doi.org/10.1017/S0267190515000070

Willis, J. (1996). A framework for task-based learning. Longman.

\section{Appendix}

The Students' Questionnaire (English translation added)

1.8月の飯田プロジエクトに参加を決めた理由を教えてください(複数回答可)。Why did you participate in this lida project held in August? (Multiple answers allowed)

- 国際交流に興味があったから I was interested in intercultural exchange.

。 人形劇·舞台芸術に興味があったから I was interested in performing arts and puppet theaters.

・英語を実践的に使ってみたかったから I wanted to use English for real-world purposes.

・ 地方の活性化に興味があったから I was interested in regional revitalization.

- その他 Others

2.AVIAMAレセプションでのプレゼンについて、調査担当都市を教えてください(複数回答可)。 Which city did you research for the presentation at the AVIAMA? (Multiple answers allowed)

3. プレゼン作成のため、どんな方法で調査しましたか(複数回答可)? To create the presentation, how did you conduct research? (Multiple answers allowed)

・ インターネット上の資料を読んだ(日本語で) Japanese sources on the internet

・インターネット上の資料を読んだ(英語で) English sources on the internet

・図書館で資料を調べた(日本語で) Japanese sources at the library

、図書館で資料を調べた(英語で) English sources at the library

外部機関を訪問した Visiting organization

- その他 Others

4. 訪問した外部機関を教えてください(複数回答可)。Which organization did you visit? (Multiple answers allowed) 


\section{JALT2020}

COMMUNITIES OF

5.飯田プロジエクト(AVIAMAプレゼン)に参加する前と比べて、「英語」や「国際交流」に対す る意識に変化はありましたか。Did you feel any change in your perceptions of English or intercultural exchange before and after participating in the lida project (the AVIAMA presentation)?

・ 大いに変化があった Greatly changed

・変化があった Changed

・ あまり変化が無かった Little changed

- 全く変化が無かった No change

6. AVIAMAレセプションでのプレゼン後、周囲(津田の教員を除く)から、感想・コメントなど、声 をかけられましたか?感想・コメントをもらった人は、具体的に書いてください。After the AVIAMA presentation, did you gain some feedback from the audience? If so, please share what kind of comments you were given.

7. AVIAMAプレゼン準備〜当日までの、津田の教員のサポートについて、感想を教えてくださ い。 How did you feel about the Tsuda teachers' support during the process of creating the AVIAMA presentation?

- 大いに役立った Very useful

・少しは役立った Useful

・ あまり役に立たなかった Rarely useful

。全く役に立たなかった Never useful

8. 飯田プロジェクト(AVIAMAプレゼンについて)を振り返つて、自分の満足度を4点満点で評価し てください。Please evaluate your satisfaction level about the AVIAMA presentation.
- 4 (大いに満足) Very satisfied
- 3 (満足) Satisfied
2 (不満足) Unsatisfied

1 1 (大いに不満足) Very unsatisfied
9. 飯田プロジェクト(アテンドについて)を振り返って、自分の満足度を4点満点で評価してくださ い。Please evaluate your satisfaction level about attending to the guests at the AVIAMA assembly.

- 4 (大いに満足) Very satisfied

- 3 (満足) Satisfied

- 2 (不満足) Unsatisfied

- 1 (大いに不満足) Very unsatisfied

10. AVIAMAでの活動をふまえ、どのように自分の今後の活動に活かしていきたいと思いますか( 複数回答可) ? Based on the activities at AVIAMA, what kind of future activities would you like to participate in? (Multiple answers allowed)

・ 外国人の方との交流の場面に積極的に参加する。Having more opportunities to communicate with foreign people

- 英語プレゼンテーションの機会に積極的に参加する。Finding more opportunities to make an English presentation

- 津田塾の地域連携活動に積極的に参加する。Participating in the projects of regional revitalization at Tsuda

・留学などのキャリアアップに挑戦する。Studying overseas

- 国際文化交流や外国文化の知識を深める活動に参加する。Participating in intercultural exchange programs

- その他 Others 